\title{
KARAKTERISTIK VEGETASI MANGROVE DAN PEMANFAATANNYA: STUDI KASUS DI SERAM TIMUR, MALUKU
}

\section{CHARACTERISTICS OF MANGROVE VEGETATION AND ITS UTILIZATION: A CASE STUDY FROM SERAM TIMUR, MALUKU}

\author{
Suyadi ${ }^{*}$, Iwan Naroli ${ }^{2}$, dan Alvi Betmanto Sitepu ${ }^{2}$ \\ ${ }^{1}$ Pusat Penelitian Biologi - LIPI. \\ Jl. Raya Bogor km 46, Cibinong 16911, Bogor \\ ${ }^{2}$ Pusat Penelitian Laut Dalam - LIPI, \\ Jl. Y. Syaranamual, Poka, Ambon \\ Email: suya009@lipi.go.id
}

(Diterima: 30 November 2020; Diterima setelah perbaikan: 15 September 2021; Disetujui: 19 September 2021)

\begin{abstract}
ABSTRAK
Mangrove adalah ekosistem yang komplek dan memiliki banyak manfaatnya, namun ekosistem ini sangat rentan terhadap berbagai gangguan. Informasi tentang karaktersitik dan kondisi mangrove serta pemanfaatannya oleh masyarakat di kawasan timur Indonesia masih sangat terbatas. Penelitian ini menerapkan GIS/Remote Sensing, transek, dan wawancara informal untuk mengungkap karakterisik mangrove dan pemanfaatannya. Hasil penelitian menunjukan bahwa mangrove di lokasi penelitian merupakan ekosistem yang unik dengan luas total 3.998 ha (mean patches size: 4ha). Penelitian mencatat 18 jenis mangrove dengan species dominan yaitu Rhizophora apiculata (INP 228) dan Sonneratia alba (INP 225). Kondisi hutan mangrove masih relatif baik, namun di beberapa lokasi sudah mengalami kerusakan. Kerapatan pohon rata-rata 136 pohon ha $^{-1}$ dan kerapatan seedling 960 pohon ha ${ }^{-1}$. Pemanfaatan mangrove masuk kedalam kategorikan pemanfaatan yang tidak ramah lingkungan seperti penebangan untuk kayu bakar untuk berbagai kebutuhan rumah tangga, industi rumahan pengasapan ikan, dan dijual. Diperlukan sistem pengelolaan mangrove yang efektif dan dukungan pemerintah dalam pemanfaatan potensi hutan mangrove secara berkelanjutan seperti ekowisata dan bioekonomi.
\end{abstract}

KATA KUNCI: Karakteristik vegetasi; ekosistem mangrove; pesisir; Maluku

\begin{abstract}
Mangrove is complex ecosystem and provides wide range of benefit, but this ecosystem is vulnerable. Information about characteristics, conditions, and utilization of mangrove by local communities in eastern part of Indonesia was limited. This study applie GIS/Remote sensing, transects, and informal interview to assess mangrove characteristics and its utilization. The result showed that mangrove in the study area is unique ecosystem with total area was 3,998 ha (mean patch size: 4 ha). The study found 18 species of mangrove. The most dominant species was Rhizophora apiculata (INP 228), followed by Sonneratia alba (INP 225). Mangrove was relatively in good condition, but mangroves in some sites were degraded. Mean density of mangrove trees was 136 stem ha ${ }^{-1}$ and mean density of seedlings was 960 pohon ha ${ }^{-1}$. Mangrove utilization was categorized as not environmental friendly use such as logging for firewood for households, small-scale industries of smoked fish, and trade. The study suggests that effective management is required and mangrove potential can be used to support sustainable use of mangrove such as ecotourism and bioeconomy.
\end{abstract}

KEYWORDS: Vegetation characteristics; mangrove ecosystem; coastal; Maluku

\footnotetext{
\# Korespondensi: Pusat Penelitian Biologi-LIPI

E-mail: suya009@lipi.go.id
} 


\section{PENDAHULUAN}

Hutan mangrove merupakan ekosistem peralihan antara darat dan laut yang umum di jumpai di daerah pesisir. Oleh karena itu, ekosistem mangrove juga disebut sebagai ekosistem transisi yang eksistensinya juga dipengaruhi oleh faktor-faktor darat dan laut (Tomlinson, 1994). Hutan mangrove juga disebut sebagai hutan pantai atau hutan pasang surut karena umumnya tumbuh pada daerah jangkauan air pasang tertinggi. Indonesia merupakan habitat mangrove terbesar (23\%) di dunia dan rumah bagi $67 \%$ species mangrove yang ada didunia (Giri et al., 2011; Noor et al., 1999). Banyak di antaranya adalah jenis-jenis mangrove endemik dan terancam punah (Noor et al., 1999, Polidoro et al., 2010).

Mangrove memiliki fungsi ekologis (habitat berbagai biota laut), nilai ekonomi, dan jasa lingkungan (ecosystem services) yang penting untuk kelestarian alam dan kehidupan manusia (Duke et al., 2007). Mangrove berfungsi sebagai benteng pertahanan pantai dari bencana alam, pencegah intruisi air lain ke darat, dan penyerap karbon (Donato et al., 2011). Mangrove juga sebagai tempat mencari makan, asuhan, tempat bertelur dan tempat mencari makan berbagai biota laut seperti ikan. Mangrove merupakan sumber penghasil makanan, minuman, obat-obatan, kayu bakar, bahan bangunan yang menjadi sumber pendapatan bagi penduduk setempat serta lokasi wisata.

Ekosistem hutan mangrove menghadapi berbagai ancaman akibat berbagai aktivitas manusia. Ancaman utama adalah deforestasi dan logging. Sekitar 27\% $40 \%$ hutan mangrove telah hilang atau terdegradasi dengan laju deforestasi dan degradasi 5\% per tahun (Murdiyarso et al., 2015; Noor et al., 1999; Ruittenbeek et al., 2014; Thomas et al., 2017). Sebagian besar hutan mangrove di konversi menjadi tambak, perumahan/pemukiman, infrasturtur pesisir, dan lahan pertanian. Logging juga meningkat hingga 93\% dengan laju penebangan hutan $14 \%$ per tahun, dimana Maluku merupakan salah satu provinsi yang mengalami peningkatan logging terbesar (51\%) (Noor et al., 1999).

Salah satu habitat mangrove di Indonesia adalah Maluku terutama di daerah Seram Timur. Maluku merupakan provinsi kepulauan terbesar di Indonesia dimana $92 \%$ wilayahnya adalah laut dengan jumlah pulau sebanyak 1.341 pulau serta memiliki garis pantai terpanjang di Indonesia. Sebagian besar pulau di Maluku adalah pulau kecil (98\%) dan sisanya adalah pulau berukuran besar $(>200 \mathrm{~km})$. Seram Timur merupakan Kabupaten yang di dalamnya mencakup pulau berukuran besar (Pulau Seram) dan pulau-pulau kecil yang merupakan habitat bagi mangrove. Masyarakat
Seram Timur mengenal mangrove dengan nama "Akat", secara spesifik akat biasanya disebutkan untuk mangrove jenis Rhizophora sp. Pembangunan di wilayah pesisir yang dilakukan secara tidak berkelanjutan dan aktivitas manusia lainnya termasuk penebangan mangrove, dan pencemaran sampah di duga menjadi ancaman utama bagi kelestatian hutan mangrove yang berdampak pada nilai ekonomi dan ekologis hutan mangrove.

Meskipun wilayah Seram Timur merupakan habitat penting bagi mangrove dan terdapat tekanan terhadap kelestarian mangrove, namun data dan informasi ilmiah tentang karakteristik vegetasi dan pemanfaatan mangrove di daerah tersebut masih sangat minim. Tujuan penelitian ini adalah untuk mengidentifikasi karaktersitik dan kondisi vegetasi mangrove dan mengunkap pemanfaatan hutan mangrove oleh masyarakat setempat. Informasi ini diperlukan sebagai basis data dalam pengelolaan mangrove dan pengembangan pemanfaatan mangrove untuk meningkatkan kesejahteraan masyarakat dan upaya konservasi hutan mangrove.

\section{BAHAN DAN METODE}

\section{Study area}

Penelitian ini dilaksanakan di Kawasan Seram Timur yakni di Pulau Keffing (Air Nanang 1; Air nanang 2; Air nanang 3; Air nanang 4), Pulau Kwamor (Solaturun Kwamor; Teonota Kwamor), dan Pulau Geser ( Wawasa 1 Seram Laut; dan Wawasa 2 Seram Laut) (Gambar 1). Seram Timur beriklim laut tropis dan iklim musim yang dipengaruhi oleh laut dan pulau-pulau kecil. Musim yang dikenal pada umumnya adalah: musim panas, musim hujan dan musim pancaroba. Musim panas terjadi selama bulan Januari-Maret dan OktoberDesember dengan arah tiupan angin adalah angin yang bertiup dari Barat ke Timur, Keadaan lautan pada umumnya tenang/gelombang kecil. Musim hujan berlangsung dari bulan Juni-Juli dengan arah tiupan angin dari Timur ke Barat. Musim pancaroba/musim peralihan terjadi selama bulan April-Mei dan AgustusSeptember arah angin bervariasi/tidak tetap (Tenggara, Selatan, Barat Daya dan Utara).

\section{Pengumpulan dan analisis data}

Penelitian ini menerapkan beberapa metode yaitu GIS/Remote Sensing, Transeck, dan wawancara informal. GIS/Remote Sensing di gunakan untuk mengetahui luas hutan mangrove yang di analisis dari citra Landsat 8 TM tahun 2016 menggunakan ArcGIS 10.2. Observasi dan wawancara informal di lakukan untuk mengungkap pemanfaatan mangrove oleh masyarakat setempat. Wawancara dilakukan dengan cara diskusi informal tanpa bantuan kuesioner dengan 
15 responden. Selanjutnya hasil di diskusi di rekap dan analisis secara deskriptif untuk mengetahui pemanfaatan mangrove dan sumberdaya hayati lainnya yang berasosiasi dengan mangrove seperti ikan, kerang, dan lain-lain.

Sebelum dilakukan pencuplikan sample (sampling), dilakukan pengamatan lapangan (field observation) yang meliputi seluruh kawasan hutan di Seram Timur yang bertujuan untuk melihat secara umum keadaan fisiognomi dan variasi vegetasi hutan serta keadaan pasang surut. Delapan titik sampling atau transek: Keffing (Air Nanang 1, Air nanang 2, Air nanang 3 , Air nanang 4), Pulau Kwamor (Solaturun Kwamor, Teonota Kwamor), dan Pulau Geser (Wawasa 1 Seram
Laut dan Wawasa 2 Seram Laut) dipilih menggunakan metode purposive random sampling. Pada setiap lokasi sampling dibuat transek memanjang dari tepi laut/sungai ke arah darat. Setiap transek data vegetasi dicuplik dengan menggunakan metode kuadrat berukuran $10 \times 10$ meter untuk pohon (diameter > $10 \mathrm{~cm}$ ) yang terletak di sebelah kanan dan atau kiri, sedang untuk belta/anakan (diameter $<10 \mathrm{~cm}$ ) dengan petak ukuran 5 x 5 meter. Pada setiap petak-petak tersebut semua tegakan diidentifikasi jenisnya diukur diameter dan tingginya serta dihitung jumlah masingmasing jenis. Data yang diperoleh dianalisa untuk mendapatkan nilai penting, kerapatan jenis dan dominasi jenis.

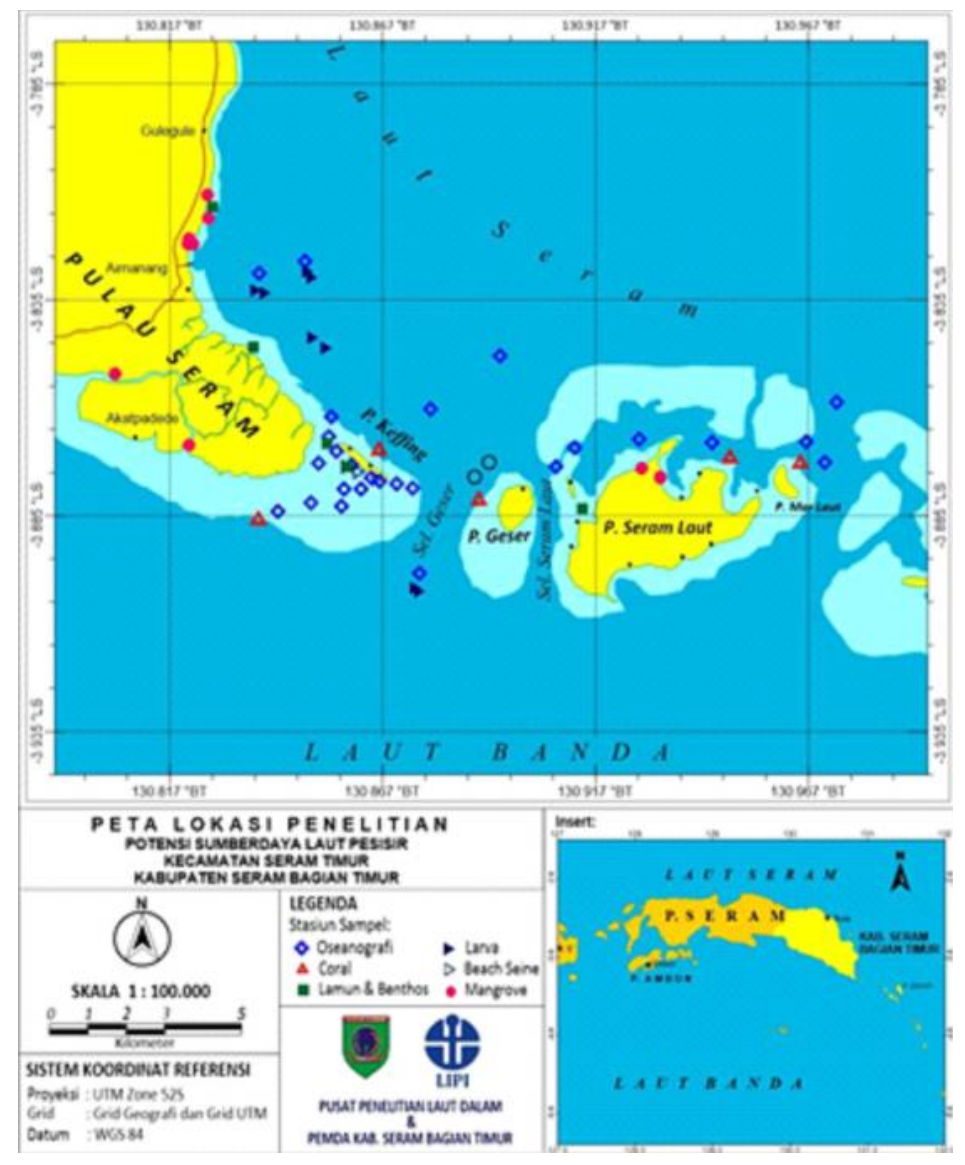

Gambar 1. Lokasi penelitian di Seram Timur, Maluku.

Figure 1. Research location of Seram Timur, Maluku.

\section{HASIL DAN BAHASAN}

\section{Luas hutan dan karakteristik vegetasi mangrove}

Hasil analisis citra Landsat 8 TM tahun 2016 menunjukkan luas total hutan mangrove di lokasi penelitian adalah 3.998 ha yang meliputi mangrove sejati (true mangrove) dan mangrove ikutan atau campuran (mangrove associate). Hutan mangrove terdistribusi di Pulau Keffing 10,68 ha (vegetasi mangrove 3,78 ha dan vegetasi campuran 6,92 ha), Pulau Kwamor 3.975,5 ha, dan Pulau Geser 11,8 ha (vegetasi mangrove 9,2 ha dan vegetasi campuran 2,6 ha) (Gambar 2). Kondisi hutan mangrove yang relatif baik dijumpai di Keffing dan beberapa pantai seperti di Seram Laut didaerah Wawasa. Namun beberapa ancaman seperti penebangan kayu dan polusi plastik di temukan di seluruh lokasi penelitian. 
Luas hutan mangrove di pulau-pulau yang termasuk dalam kategori pulau kecil $\left(<2000 \mathrm{~km}^{2}\right)$ seperti Pulau Keffing dan Pulau Geser memiliki rata total luas hutan mangrove 11 ha, dengan rata-rata luas mangrove patches sekitar 4 ha (Gambar 2). Penelitian di pulaupulau kecil lainnya seperti Teluk Ambon, Teluk Weda, dan Pulau Buru juga menunjukan karakteristik yang serupa yaitu mangrove di pulau-pulau kecil membentuk spot-spot kecil mangrove patches
(Suyadi, 2012; Suyadi, 2014). Sebaliknya, luas total hutan mangrove di Pulau Kwamor (> 2000km) jauh lebih luas yaitu hingga 3975 ha dan membentuk mangrove patches yang cukup luas, rata-rata (600 ha). Hutan mangrove di pulau-pulau berukuran besar ( $>$ $2.000 \mathrm{~km}$ ) seperti di Bintuni (Papua), Cilacap (Jawa), Weda (Halmahera), dan Batam (Sumatra) juga memiliki ukuran patches yang besar (Pramita, 2018; Suyadi, 2014; Irawan dan Malau, 2016).

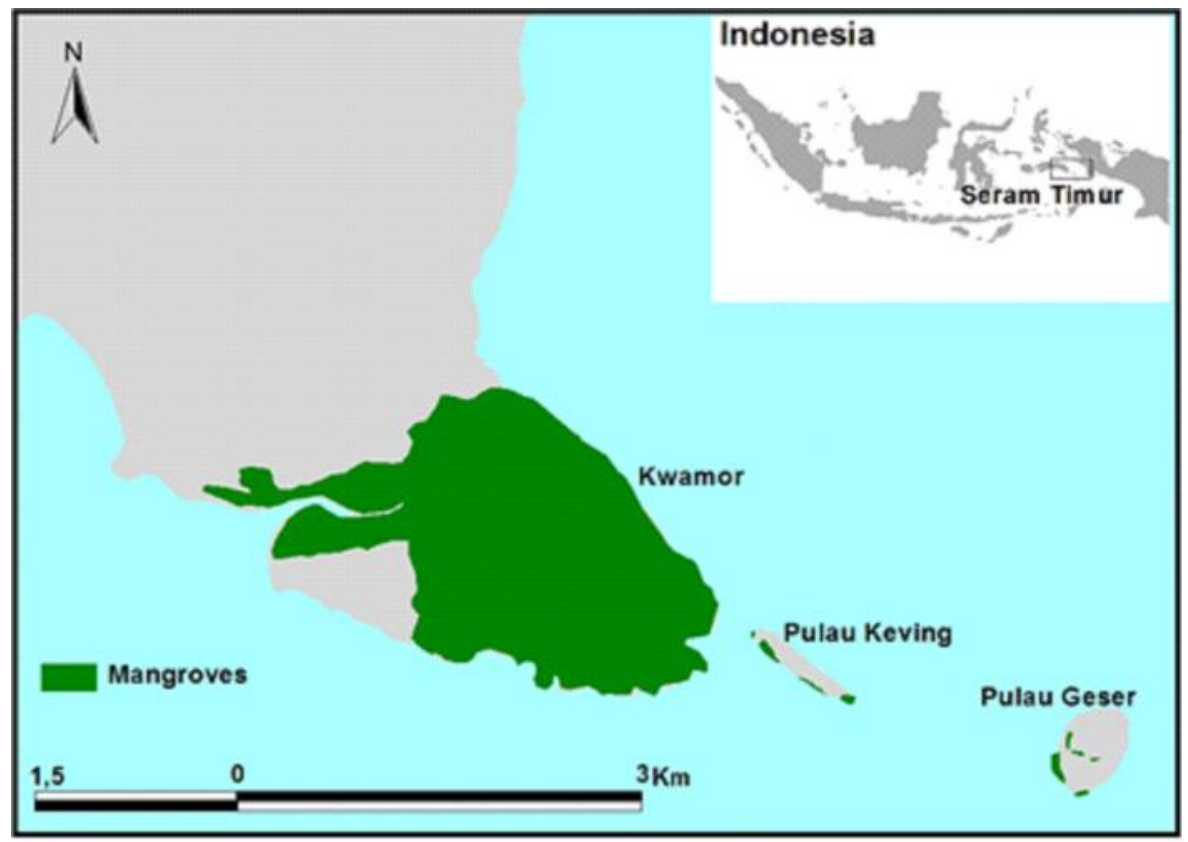

Gambar 2. Tutupan hutan mangrove di lokasi penelitian (Kwamor, Keffing, dan Pulau Geser), Seram Bagian Timur, Maluku, Indonesia.

Figure 2. Mangrove forest cover in study sites (Kwamor, Keffing, dan Pulau Geser), Seram Bagian Timur, Maluku, Indonesia.

Transek dan koleksi bebas berhasil mencatat sebanyak 18 jenis mangrove dari 11 famili di lokasi penelitian (Lampiran). Dari total jumlah spesies tersebut 15 spesies diantaranya adalah mangrove sejati dan 3 spesies lainnya adalah mangrove ikutan. Secara umum kondisi mangrove di lokasi penelitian masih relatif baik, kecuali di Kwamor dan Geser kondisi mangrove masuk kategori kurang sehat. Rata-rata kerapatan mangrove di lokasi penelitian adalah 136 pohon ha-1 dengan rata-rata kerapatan tertinggi di Keffing yaitu 164 pohon ha-1. Analisa vegetasi mangrove di delapan transek (Air Nanang 1, Air nanang 2, Air nanang 3, Air nanang 4, Solaturun Kwamor, Teonota Kwamor, Wawasa 1 Seram Laut, dan Wawasa 2 Seram Laut) menunjukkan bahwa Rhizophora apiculata dan Sonneratia alba memiliki kerapatan yang

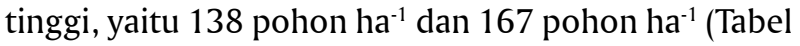
1). Ini artinya bahwa ekosistem mangrove di Seram Timur di dominasi oleh jenis Rhizophora apiculata dan Sonneratia alba.
Hasil analisis index nilai penting menunjukkan bahwa Rhizophora apiculata dan Sonneratia alba memiliki indek tertinggi di lokasi penelitian (Tabel 2). Jenis-jenis ini merupakan jenis kosmopolit yang di jumpai di seluruh lokasi penelitian. Jenis Bruguiera parviflor; Avicennia officinalis, Xylocarpus granatum, dan Osbornia octodonta hanya di jumpai di Kwamor dan Geser (Table 2). Dominasi jenis di studi area berbeda dengan ekosistem mangrove yang ada di Teluk Weda (Halmahera), namun sama dengan di Pulau Ambon (Suyadi, 2012; Suyadi, 2014). Kemiripan dengan Pulau Ambon karena sama-sama pulau kecil dimana mangrove tumbuh di sepanjang garis pantai yang sempit $( \pm 500 \mathrm{~m})$ dan substrat yang agak berpasir dengan ukuran partikel antara 0,1 - $2 \mathrm{~mm}$ (Suyadi 2012). Berbeda dengan di Teluk Weda, Halmahera yang merupakan pulau besar dengan karakteristik pantai yang lebih landai dan relatif luas $(( \pm 1000 \mathrm{~m})$ dan substrat dominan lanau (silt) dan lempung (clay) ukuran partikel $<0,1 \mathrm{~mm}$ (Suyadi 2014; Suyadi 2020). Kondisi 
lingkungan seperti geomorfologi pantai dan substrat atau lingkunan merupakan syarat tumbuh mangrove (Duke et al., 1998; Spalding et al., 2011).

Analisis kerapatan seedling juga menunjukkan hasil yang serupa dengan tingkat pohon dimana jenis Rhizophora apiculata dan Sonneratia alba juga merupakan spesies yang dominan untuk tingkat anakan mangrove (seedling), masing-masing mencapai 1.700 pohon ha-1 dan 500 pohon ha-1 (Tabel 3). Jenis Rhizophora apiculata dan Sonneratia albajuga memiliki indek nilai penting yang tinggi masing-masing yaitu mencapai 248 dan 68 (Tabel 4). Karakterisik serupa juga ditemukan di Teluk Ambon dan Teluk Weda, dimana jenis yang dominan pada tingkat seedling sama dengan pada tingkat pohon (Suyadi, 2012; Suyadi, 2014). Hal tersebut umum terjadi karena sebaran dan tingkat survival anakan mangrove (mangrove establishment) di pengaruhi oleh keberadaan induknya (Duke, 1998).
Namun, studi ini juga menemukan bahwa anakan Ceriops tagal merupakan jenis mangrove yang memiliki indek nilai penting tertinggi ketiga yaitu hingga 117 dan terdistribusi hampir merata di seluruh transek. Sementara itu induk (pohon) Ceriops tagal tidak dominan (Tabel 1 dan 2) dan tidak tersebar merata di semua transek. Hasil tersebut dapat menjadi indikator kemungkinan potensi adanya perubahan dominasi species (species shifting) di masa yang akan datang. Namun penelitian lebih lanjut masih diperlukan untuk memastikan adanya kemungkinan species shifting tersebut. Perubahan dominasi species (species shifting) bisa terjadi akibat beberapa hal berikut kompetisi antar spesies (species competition), perubahan lingkungan (environmental change) seperti perubahan substrat dan suhu, dan faktor manusia (introduksi species) (Duke et al., 1998; Spalding et al., 2011).

Tabel 1. Kerapatan pohon mangrove di delapan daerah pengamatan/transek.

Table 1. Density of mangrove tree in eight sampling site/transects

\begin{tabular}{lcccccccc}
\hline \multicolumn{1}{c}{ Jenis } & \multicolumn{10}{c}{ Transek $\left(\right.$ pohon ha $\left.^{-1}\right)$} \\
\cline { 2 - 9 } & $\mathbf{1}$ & $\mathbf{2}$ & $\mathbf{3}$ & $\mathbf{4}$ & $\mathbf{5}$ & $\mathbf{6}$ & $\mathbf{7}$ & $\mathbf{8}$ \\
\hline Rhizophora apiculata & $\mathbf{1 7}$ & $\mathbf{1 3 8}$ & $\mathbf{1 3 8}$ & $\mathbf{1 3 3}$ & $\mathbf{8 0}$ & $\mathbf{7 0}$ & $\mathbf{5 0}$ & $\mathbf{6}$ \\
Bruguiera gymnorrhiza & 133 & 38 & - & - & 30 & - & - & - \\
Bruguiera parviflora & - & - & - & - & - & 30 & - & - \\
Ceriops tagal & - & - & 63 & - & - & 20 & - & - \\
Sonneratia alba & $\mathbf{1 6 7}$ & - & - & $\mathbf{3 3}$ & $\mathbf{1 2 0}$ & $\mathbf{5 0}$ & $\mathbf{1 2 5}$ & $\mathbf{9 4}$ \\
Avicennia officinalis & 17 & - & - & - & - & - & - & 22 \\
Xylocarpus granatum & - & - & - & - & - & 130 & - & - \\
Osbornia octodonta & - & - & - & - & - & - & - & 17 \\
\hline
\end{tabular}

Keterangan: 1. Air Nanang 1; 2 . Air nanang 2; 3. Air nanang 3; 4. Air nanang 4; 5. Solaturun Kwamor; 6. Teonota Kwamor; 7. Wawasa 1 Seram Laut; 8. Wawasa 2 Seram Laut.

Tabel 2. Indek Nilai Penting pohon mangrove di delapan daerah pengamatan/transek

Table 2. Important index of mangrove tree in eight sampling sites/transects

\begin{tabular}{|c|c|c|c|c|c|c|c|c|}
\hline \multirow[t]{2}{*}{ Jenis } & \multicolumn{8}{|c|}{ Transek } \\
\hline & $\mathbf{1}$ & 2 & 3 & 4 & 5 & 6 & 7 & 8 \\
\hline $\begin{array}{l}\text { Rhizophora } \\
\text { apiculata }\end{array}$ & 23.7 & 227.5 & 202.9 & 210.3 & 104.3 & 68.8 & 75.4 & 20.9 \\
\hline $\begin{array}{l}\text { Bruguiera } \\
\text { gymnorrhiza }\end{array}$ & 102 & 72.5 & - & - & 50 & - & - & - \\
\hline Bruguiera parviflora & - & - & - & - & - & 32.5 & - & - \\
\hline Ceriops tagal & - & - & 97.1 & - & - & 21 & - & - \\
\hline Sonneratia alba & 150.2 & - & - & 89.7 & 145.7 & 49.6 & 224.6 & 176.9 \\
\hline Avicennia officinalis & 24 & - & - & - & - & - & - & 50.1 \\
\hline $\begin{array}{l}\text { Xylocarpus } \\
\text { granatum }\end{array}$ & - & - & - & - & - & 128 & - & - \\
\hline Osbornia octodonta & - & - & - & - & - & - & - & 52 \\
\hline
\end{tabular}


Tabel 3. Kerapatan anakan mangrove di delapan daerah pengamatan /transek

Table 3. Density of seedlings in eight sampling sites/transects

\begin{tabular}{lcccccccc}
\hline \multicolumn{1}{c}{ Jenis } & \multicolumn{8}{c}{ Transek (pohon ha } \\
\cline { 2 - 9 } & $\mathbf{1}$ & $\mathbf{2}$ & $\mathbf{3}$ & $\mathbf{4}$ & $\mathbf{5}$ & $\mathbf{6}$ & $\mathbf{7}$ & $\mathbf{8}$ \\
\hline Rhizophora apiculata & - & $\mathbf{6 0 0}$ & $\mathbf{1 5 0 0}$ & $\mathbf{8 0 0}$ & $\mathbf{6 4 0}$ & $\mathbf{3 2 0}$ & $\mathbf{1 7 0 0}$ & $\mathbf{1 0 6 7}$ \\
Rhizophora stylosa & - & 100 & - & - & 240 & - & - & - \\
Bruguiera gymnorrhiza & 267 & 250 & - & - & 400 & - & - & - \\
Bruguiera parviflora & - & - & - & - & - & 80 & - & - \\
Ceriops tagal & 67 & - & 400 & 200 & - & 600 & - & 1067 \\
Sonneratia alba & $\mathbf{2 0 0}$ & - & - & - & $\mathbf{2 4 0}$ & $\mathbf{1 6 0}$ & $\mathbf{5 0 0}$ & $\mathbf{1 7 8}$ \\
Aegiceras corniculatum & 867 & - & - & - & - & 80 & - & 133 \\
Xylocarpus granatum & - & - & - & - & - & 440 & - & - \\
Osbornia octodonta & - & - & - & - & - & - & - & 222 \\
\hline
\end{tabular}

Tabel 4. Indek Nilai Penting anakan mangrove di delapan daerah pengamatan/transek

Table 4. Important index of seedlings in eight sampling sites/transects

\begin{tabular}{lcccccccc}
\hline \multicolumn{1}{c}{ Jenis } & \multicolumn{10}{c}{ Transek } \\
\cline { 2 - 9 } & $\mathbf{1}$ & $\mathbf{2}$ & $\mathbf{3}$ & $\mathbf{4}$ & $\mathbf{5}$ & $\mathbf{6}$ & $\mathbf{7}$ & $\mathbf{8}$ \\
\hline Rhizophora apiculata & - & $\mathbf{1 5 6 . 5}$ & $\mathbf{2 3 6 . 2}$ & $\mathbf{2 4 8}$ & $\mathbf{1 2 2 . 3}$ & $\mathbf{6 2}$ & $\mathbf{2 3 4}$ & $\mathbf{1 1 7 . 1}$ \\
Rhizophora stylosa & - & 41.2 & - & - & 36.5 & - & - & - \\
Bruguiera gymnorrhiza & 61 & 102.3 & - & - & 88.2 & - & - & - \\
Bruguiera parviflora & - & - & - & - & - & 18.2 & - & - \\
Ceriops tagal & $\mathbf{2 0 . 7}$ & - & $\mathbf{6 3 . 8}$ & $\mathbf{5 2}$ & - & $\mathbf{9 6 . 7}$ & - & $\mathbf{1 1 7 . 3}$ \\
Sonneratia alba & $\mathbf{6 7 . 7}$ & - & - & - & $\mathbf{5 3}$ & $\mathbf{2 9 . 8}$ & $\mathbf{6 6}$ & $\mathbf{2 6 . 4}$ \\
Aegiceras & 150.6 & - & - & - & - & 14.6 & - & 11.9 \\
corniculatum & & - & - & - & - & 78.6 & - & - \\
Xylocarpus granatum & - & - & - & - & - & - & - & 27.3 \\
Osbornia octodonta & - & - & - & - & - &
\end{tabular}

\section{Potensi dan pemanfaatan mangrove}

Masyarakat setempat memanfaatkan mangrove sebagai kayu bakar (Gambar 3) dan sebagian kecil memanfaatkan sebagai bahan bangunan. Pemanfaatan mangrove sebagai kayu bakar dapat dibagi menjadi tiga kategori yaitu: (1) pengambilan kayu bakar untuk memasak sehari-hari, (2) pengambilan kayu bakar untuk keperluan pengasapan pada industri rumahan ikan julung asar (3) Pengambilan kayu bakar untuk di jual. Pemanfaatan mangrove sebagai kayu bakar nampaknya cukup intensif dan massif karena bukan hanya untuk tujuan rumah tangga namun juga tujuan komersil dan industri rumahan. Penebangan mangrove untuk kayu bakar perlu di kontrol dengan baik karena dapat menyebabkan fragmentasi hutan yang akhirnya menurunkan kesehatan ekosistem hutan mangrove (Suyadi et al., 2018). Salah satu dampak dari kerusakan ekosistem hutan mangrove adalah menurunnya fungsi ekologis dan jasa lingkungan hutan tersebut (Duke et al., 1998; Spalding et al., 2011, Tomlinson, 1994).
Bentuk pemanfaataan lain oleh masyarakat adalah pemanfaatan biota yang ada di ekosistem hutan mangroveseperti kerang, kepiting dan biota yang berasosiasi dengan mangrove (seperti ikan dan cacing laor). Kepiting, kerang, dan ikan bukan hanya dimanfaatkan untuk konsumsi, tetapi juga untuk tujuan komersil atau dijual. Di bagian Selatan Keffing mangrove berasosiasi dengan lamun yang merupakan lokasi munculnya cacing laor (Polychaeta) yang banyak dimanfaatkan masyarakat sebagai sumber protein. Cacing laor memiliki kandungan protein yang tinggi dan umum di konsumsi oleh masyarakat Maluku (Pamungkas, 2011). Di beberapa tempat di Maluku masyarakat memiliki tradisi untuk pemanfaatan laor yang di kenal dengan timba laor (Pamungkas, 2011).

Hutan mangrove di Pulau Kwamor membentuk spot-spot delta yang membentuk celah-celah sungai yang menghubungkan desa satu dengan desa lain atau antara desa dengan laut. Sungai-sungai tersebut digunakan sebagai jalur transportasi bagi masyarakat 
baik untuk angkutan penumpang maupun barang (Gambar 4). Keberadaan mangrove seolah menjadi benteng yang melindungi jalur transportasi tersebut dari hempasan gelombang dan arus air yang kuat. Selain itu, mangrove juga mencegah terjadinya pendangkalan sungai karena kemampuannya dalam memerangkap dan menahan sedimen (Suyadi, 2012; Suyadi, 2014).

Pengamatan menunjukan bahwa mangrove di lokasi penelitian merupakan habitat berbagai biota laut seperti ikan samandar (Siganus sp.), ikan bubara (Caranx sp.) dan ikan kakap (Lutjanus sp.) dan habitat satwa liar seperti burung dan reptilia. Mangrove juga di kenal sebagai penyerap karbon yang baik (Donato et al., 2011). Hal tersebut menunjukkan bahwa mangrove di daerah tersebut dapat dikelola dan dimanfaatkan secara berkelanjutan dan lebih ramah lingkungan untuk meningkatkan kesejahteraan masyarakat. Adanya alur sungai dan kanekaragaman biota laut dan satwa liar di hutan mangrove merupakan potensi yang dapat dikembangkan menjadi tempat edu-ekowisata bahari berbasis hutan mangrove. Hasil hutan mangrove non-kayu (buah, daun, bunga, dan lainlain) juga dapat dikembangkan sebagai bahan baku pangan / jajanan, minuman, dan kerajinan.

Pemanfaatan hutan mangrove di lokasi penelitian (Seram Timur) termasuk kedalam kategori ekstraksi kayu dan biota yang hidup di hutan mangrove. Tipe pemanfaatan seperti ini dapat merusak ekosistem hutan mangrove, tidak berkelanjutan, dan nilai ekonominya yang diperoleh masyarakat rendah. Tipe pemanfaatan hutan mangrove seperti ini serupa dengan pemanfaatan hutan mangrove di kawasan Indonesia Timur lainnya seperti di Weda, Maluku Utara dan Ambon (Suyadi, 2012; Suyadi, 2014). Hal tersebut berbeda dengan tipe pemanfaatan hutan mangrove di daerah Jawa (seperti di daerah Cilacap) dan Kalimantan (seperti di daerah Berau) dimana pemanfaatan hutan mangrove sudah mulai bersifat non ekstraktif dan relatih ramah lingkungan seperti pemanenan buah untuk dibuat makanan kecil (snack), getah untuk pewarna, dan ekoeduwisata bahari berbasis hutan mangrove (Pramita, 2018; Mulyadi et al., 2015). Ini berarti mangrove berpotensi sebagai bahan baku untuk pengembangan industri kreatif yang ramah lingkungan. Beberapa aspek yang diperlukan masyarakat untuk mengembangkan industri kreatif dengan memanfaatkan mangrove secara berkelanjutan dan ramah lingkungan adalah adanya dorongan dari pemerintah, pendampingan dan pelatihan, regulasi yang mendukung, dan sarana infrastuktur. Pelatihan dan pendampingan diperlukan untuk meningkatkan pengetahuan, skill, kreatifitas masyarakat, dan membangun usaha seperti koperasi dan UMKM. Pada era industri 4.0 ini, pemanfaatan biodiversitas termasuk mangrove dan biota asosiasinya hendaknya lebih maju sehingga dapat memberikan nilai ekonomi yang lebih tinggi dan dapat menjamin konservasi biodiversitas seperti melalu mekanisme bioprospeksi (seperti jamu, obat herbal terstandar, fitofarmaka, imunodulator) dan bioekonomi seperti biodiversity finance initiative dari UNDP dan carbon finance initiative dari luar negeri.

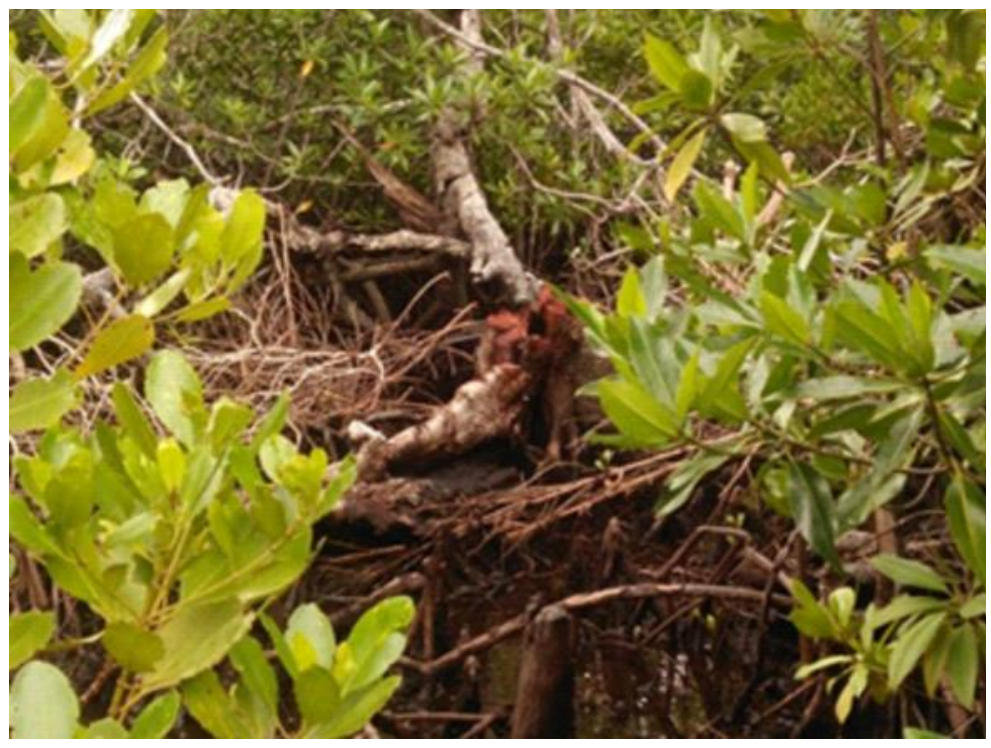

Gambar 3. Penebangan pohon mangrove yang dimanfaatkan masyarakat sebagai bahan bakar rumah tangga, industri rumahan ikan asap, dan di jual.

Figure 3. Mangrove logging for fuelwood of household, smoked fish small scale industries, and small sacle trade. 


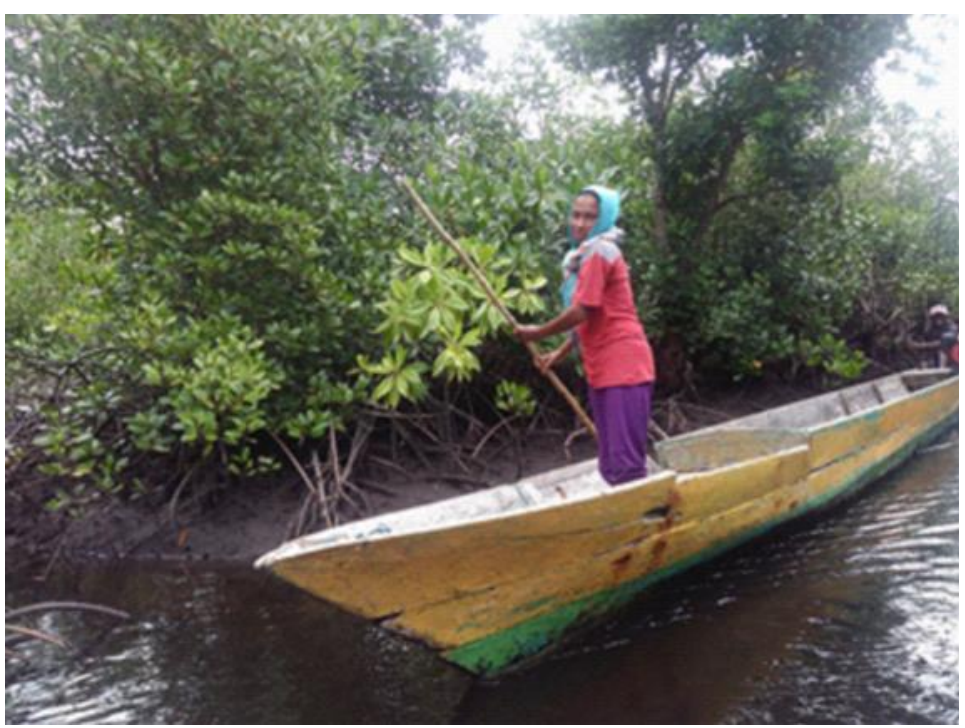

Gambar 4. Masyarakat setempat menggunakan alur-alur sungai di antara hutan mangrove sebagai jalur transportasi untuk mengangkut barang dan penumpang.

Figure 4. Local communities use river channels (creek) among mangrove forest patches as transportation network to transport passenggers and goods.

\section{KESIMPULAN}

Mangrove di Seram Timur merupakan ekosistem mangrove khas pulau-pulau kecil dan pulau besar. Secara umum kondisi mangrove masih cukup baik terutama di Kwamor dan Seram Laut. Rata-rata kerapatan mangrove adalah 136 pohon ha $^{-1}$ dengan jenis dominan Rhizophora apiculata dan Sonneratia alba. Ekosistem mangrove memiliki potensi yang bagus dan dapat $\mathrm{di}$ manfaatkan untuk meningkatkan pendapatan masyarakat setempat. Namun, pemanfaatan hutan mangrove saat ini masih bersifat ekstraktif yang tidak ramah lingkungan seperti penebangan untuk kayu bakar. Model pengelolaan ekosistem mangrove yang ramah lingkungan dan berbasis komunitas seperti eduekowisata diperlukan untuk menjamin kelestarian hutan mangrove sekaligus meningkatkan kesejahteraan masyarakat. Dorongan dan dukungan dari pemerintah seperti pelatihan dan pendampingan, regulasi, dan sarana-prasarana diperlukan untuk mewujudkan pemanfaatan ekosistem mangrove yang ramah lingkungan tersebut.

\section{UCAPAN TERIMA KASIH}

Semua penulis menyepakati bahwa Suyadi adalah kontributor utama dalam karya ilmiah ini sedangkan Iwan Naroli dan Alvi Betmanto Sitepu adalah kontributor anggota. Penulis mengucapkan terima kasih kepada bapak Abraham Simon Leatemia dan pihak-pihak lain yang telah membantu dalam penelitian.

\section{DAFTAR PUSTAKA}

Donato, D. C., Kauffman, J. B., Murdiyarso, D., Kurnianto, S., Stidham, M., \& Kanninen, M. (2011). Mangroves among the most carbon-rich forests in the tropics. Nature Geoscience, 4(5), 293-297, DOI: 10.1038/NGEO1123.

Duke, N. C., Meynecke, J., Dittmann, S., Ellison, A. M., Anger, K., Berger, U., Field, C. D. (2007). A world without mangroves? Science, 3175834), 4142.

Duke, N., Ball, M., \& Ellison, J. (1998). Factors influencing biodiversity and distributional gradients in mangroves. Global Ecology \& Biogeography Letters, 71), 27-47.

Giri, C., Ochieng, E., Tieszen, L. L., Zhu, Z., Singh, A., Loveland, T., Duke, N. (2011). Status and distribution of mangrove forests of the world using earth observation satellite data. Global Ecology and Biogeography, 20(1), 154-159, DOI: 10.1111/j.1466-8238.2010.00584.x.

Irawan S. \& Malau, A. O. (2016). Analisis persebaran mangorove di Pulau Batam menggunakan teknologi penginderaan jauh. Jurnal integrasi. Vol. 8, No. 2, 80-87.

Mulyadi, E., Hendriyanto, O., Fitriani, N. (2015). Konservasi Hutan Mangrove Sebagai Ekowisata. Jurnal Ilmiah Lingkungan, Vol 1 Edisi Khusus, hlm. 51-58.

Noor, Y.R., Khazali, M., I.N.N. Suryadiputra. (1999). Panduan Pengenalan Mangrove di Indonesia. PHKA WI-IP, Bogor. 
Pamungkas, J. (2011) Delicious! Marine worms from Ambon Island, Indonesia. Marine Habitat Magazine. Issue 2.

Pramita, S. B. (2018). Kajian kerusakan lingkungan ekosistem mangrove akibat aktivitas pemanfaatan lahan di ujung alang Kabupaten Cilacap. Tesis master program studi Ilmu Linskungan, Sekolah Pascasarjana, Universitas Gadjah Mada.

Polidoro, B.A., Carpenter, K.E., Collins, L., Duke, N.C., Ellison, A.M., Ellison, J.C., Farnsworth, E.J., Fernando, E.S. Kathiresan, K., Koedam, N. E., Livingstone, S.R., Miyagi, T., Moore, G., Nam, V, N., Ong, J. E., Primavera, J. H., Salmo, S. G., Sanciangco, J.C., Suardjo, S., Wang, Y., Yong, J.W.H. (2010). The loss of species: Mangrove extinction risk ad geographic areas of global concern. PLoS ONE 5(4): e10095. doi:10.1371/ journal.pone.0010095.

Spalding, M., Kainuma, M., \& Collins, L. (2011). World atlas of mangroves. Wetlands, 31, 1003-1005. DOI: 10.1007/s13157-011-0224-1

Suyadi (2020). Characteristics of mangrove ecosystems in Weda Bay: Environment, Vegetation, and Aboveground Carbon Stocks. IOP Conf. Series: Earth and Environmental Science 618. DOI:10.1088/ 1755-1315/618/1/012021

Suyadi; J. Gao; C. J. Lundquist; L. Scwhendennmann. (2018). Characterizing changes of temperature mangroves using spatial metrics and their rekationship with environmental factors. Estuarine, Coastal and Shelf Science. DOI.org/ 10.1016/j.ecss.2018.10.005

Suyadi (2014). Laporan penelitian ekosistem mangrove di Teluk Weda. Balai Konservasi Biota LautLembaga Ilmu Pengetahuan Indonesia (tidak di publikasikan).

Suyadi (2012). A Decade of Condition of Mangrove Forest in Ambon Bay, Maluku, Indonesia. Jurnal Biologi Indonesia. 8(1): 197 - 203.

Thomas, N., Lucas, R., Bunting, P., Hardy, A., Rosenqvist, A., \& Simard, M. (2017). Distribution and drivers of global mangrove forest change, 1996-2010. PloS One, 12(6), DOI.org/10.1371/ journal.pone.0179302.

Tomlinson (1994). The Botany of Mangroves. Cambridge University Press. 